\title{
Gilles Deleuze and Education
}

\author{
Jūratè Baranova \\ Lithuanian University of Educational Sciences \\ Professor at the Department of Education and Philosophy
}

\begin{abstract}
This article raises the question of the possibility to use some theoretical insights of Deleuze and Guattari for solving particular problems arising in education. The author discusses the concept of bodymind education formulated by Semetsky from the Deleze's example of learning as swimming. The author doubts if learning as representation is not valuable in some unexpected situations. She also describes the real example of the successful bodymind learner who experienced failure in university studies in order to involve the Deleuzian/Guattarian opposition to vertical learning and the idea of transversality as the possible solution for unsuccessful learning in university situation.
\end{abstract}

Keywords: Deleuze, Guattari, bodymind learning, vertical education, transversality, schizoanalysis

\section{Deleuze and Postmodern Education}

French philosopher Gilles Deleuze (1925-1995) is considered as belonging to postmodern or neo-Nietzschean philosophy. What possible influence of his ideas can be observed in the contemporary philosophy of education? Robin Usher and Richard Edwards in the book Postmodernism and Education: Different Voices, Different Worlds argue that education is particularly resistant to the postmodern 'message'. They notice that educational theory and practice is founded on the discourse of modernity and its self-understandings have been forged by that discourse's basic and implicit assumptions: "Historically, education can be seen as the vehicle by which modernity's 'grand narratives', the Enlightenment ideals of critical reason, individual freedom, progress and benevolent change, are substantiated and realised. The very rationale of the educational process and the role of the educator is founded on modernity's self-motivated, self-directing, rational subject, capable of exercising individual agency. Postmodernism's emphasis on the inscribed subject, the decentred subject constructed by language, discourses, desire and the unconscious, seems to contradict the very purpose of education and the basis of educational activity" (Usher, Edwards 1993: 2). On the other side, Usher and Edwards succeed to discern the postmodern message enriching the contemporary philosophy of education in the philosophical writings of Jacques Derrida, Jacques Lacan, Michel Foucault and Jean-François Lyotard. Their intention has been to get away from an educational discourse, which constructs experiential learning in logocentric terms as a 'natural' characteristic of the individual learner (see Usher 1993). Instead, they have tried to locate experiential learning in its context by showing how a number of disparate groups-new middle classes, new right-wing governments, feminists-are able to articulate their cultural assumptions and strategies within the contestable and ambiguous terrain it offers. By locating it in its context, we can begin to discern why a language or discourse (pre-text) of experiential learning has been both an effect and a condition of these developments. They maintain that "while each writer has been placed within the new paradigm, they articulate on the different theoretical positions within it; "On this basis, Lacan, with a starting point in structuralism, examines the 'laws' of language through which people become subjects and thus questions the modernist assumption that the subject is the reference point of thought and action; Derrida, more clearly a post-structuralist, undermines the modern conception of reason and rationality and its associated logocentrism, and thus opens up the question of the suppression of difference in education; Foucault, in his analysis of the pervasiveness of modern disciplinary power and the effects of regimes of truth, is usually considered a post-structuralist, although he would strenuously resist categorisation; and Lyotard is perhaps more explicitly postmodernist in addressing the postmodern moment through his critique of grand narratives and examination of the performativity of contemporary knowledge and possible responses to it" (Usher, Edwards 1993: 208-209). Usher and Edwards argue that there is a very real sense in which Lyotard, like Foucault, Derrida and Lacan, challenges us to rethink 
the nature of knowledge and the function of education, at a time when the grand narratives are under challenge by postmodern developments and the linked but not identical criterion of performativity".

But Usher and Edwards do not mention Deleuze and do not discuss his possible input into the field of the theories of contemporary education. The popularity of Deleuze's philosophy is highly visible, especially in the areas of cultural studies, politics, gender studies and the like. But in the $20^{\text {th }}$ century Foucault, Derrida and Lyotard became more integrated into the contemporary philosophy of education. It has to be admitted that in the $21^{\text {st }}$ century the influence of Deleuze's ideas on the philosophy of education is gradually increasing. Deleuze and Guattari's insights are evaluated as a challenge to different aspects of education. William Reynolds and Julie Weave responded to Deleuze and Guattari's challenge reflecting the curriculum problems (Expanding Curriculum Theory, 2002). The curriculum aspects were also discussedby Jason J.Wallin (A Deleuzian Approach to Curriculun. Essays on a Pedagogical Life, 2010). The Nomadic aspects of education were taken into consideration by Kaustav Roy (Nomadic Spaces, 2003) and Inna Semetsky (Nomadic Education, 2008). Liselott Mariett Olsson relies on Deleuze discussing the creativity and experimental aspects in early childhood education (Movement and Experimentation in Young Children's Learning. Deleuze and Guattari in Early Childhood Education, 2009). Matthew Carlin and Jason Wallin edited and published a volume emphasizing Deleuzian/Guatatrian input into the social and political aspects of education (Deleuze and Guattari.Politics of Education: For a People - Yet - To- Come, 2014). C. Beighton related Deleuzian insights with the perspective of lifelong learning (Deleuze and Lifelong Learning: Creativity, Events and Ethics, 2015). Jan Jagodzinski edited and published the volume revealing the possibilities to integrate the insights of Deleuze into the art education (What is Art Education? After Deleuze and Guattari, 2017).

However, the investigation of different aspects of possible Deleuze's input into education do not unite Deleuze's ideas with the tradition of postmodern philosophy. The social situation has changed. Inna Semetsky in the book Deleuze, Education and Becoming approaches the Deleuzean texts from the standpoint of contemporary philosophy of education. She relates her reading with the Deleuze's beloved concept of becoming (devenir) stemming from Nietzsche and discusses the Deleuze's message from the point of view of six possible becomings: becoming-Other, becoming-Sign, becomingLanguage, becoming-Rhizoma, becoming-Nomad, becoming-Child. The only postmodern philosopher not speaking about Deleuze, Semetsky mentions, is American Richard Rorty. However, he is here for the reason he is an American neopragmatist but not a postmodern thinker. Semetsky envisages the sources of American pragmatism in the possible Deleuzian input into contemporary philosophy of education. Does the conception of postmodern education lost its significance?

The researchers notice that while Foucault genealogy describes the disciplinary society used by the image of panopticum, which symbolized the centralized power of control, in the $21^{\text {st }}$ century the bio-political power functions in collusion with the decoding of social political codes. "While panoptic powers functioned by means of restraint and confinement, what Deleuze dubs control society functions by 'freeing the subject' into complex meshwork of registration and consumption. This turn is apparent in the contemporary reconceptualization of the University as a space of 'consumes choice', flexible transfer credits and pliable modes of distance delivery" (Carlin, Wallin 2014: xxii).

The aim of this article is to take up the challenge of Deleuze and Guattari's idea on education in order to find the possible ways out and suggest the solution to the problem stemming from the clash of bodymind conception of education and vertical model of university education, relying on the real unsuccessful case in education of not being able to integrate a student.

\section{Why the Allegory of Swimming is so Important for Deleuzian Input for Education?}

One of the most popular ideas suggested by Deleuze for education and explored further by the different scholars is the comparison of education with the process of swimming. It has to be admitted that Deleuze never wrote a book or a chapter on education. Just at the very beginning of his book Difference and Repetition (Différence et repetition, 1968), he was trying to sketch the point of interferences and intersections between the two lines: one concerning the essence of repetition, the other the idea of difference. In order to make his argument clear, Deleuze turned to the example of swimming as the example of education demonstrating the intersections between the difference and repetition. The motor body movements of the swimmer seem to be the reproduction of the Same. But Deleuze says it is a superficial conclusion. Deleuze reminds that even the simplest imitation involves a difference between inside and outside. According to him, imitation plays only a secondary and regulatory role in the acquisition of a behavior: it permits the correction of movements being made, but not their instigation. Deleuze wrote: "Learning takes place not in the relation between a representation and an action (reproduction of the Same) but in the relation between a sign and a response (encounter with the Other)" (Deleuze 1994: 
22). Deleuze classifies the heterogeneity involved by signs in three possible ways: 1 . the object bears or emits signs, but it happens necessarily on a different level, "as though there were two orders of size or disparate realities between which the sign flashes". 2. A sign envelops another 'object' within the limit of the object which bears it, and incarnates a natural or spiritual power; 3 . In the response, they elicit since the movement of the response does not 'resemble' that of a sign. The same happens with the movements of the swimming instructions which ares reproduced before entering the water on the sand. These movements of the 'swimming on the sand' bear no relation to the movements on the wave, which the beginner learns to deal with only by grasping the former practice as signs. Deleuze concludes that it "is difficult to say how someone learns: there is an innate or acquired practical familiarity with signs, which means that there is something amorous - but also something fatal - about all education. We learn nothing from those who say: "Do as I do". Our only teachers are those who tell us: "Do it with me" and are able to emit signs to be developed in heterogeneity rather than propose gestures for us to reproduce" (Deleuze 1994: 23). What is the difference between 'fais comme moi' and 'fais avec moi'? (Deleuze 1968: $35)$.

This is the famous extract about learning discussed by various scholars. Inna Semetsky and Diana Masny indicate that it is "extremely significant for educational theory and pedagogical practice" (Semetsky, Masny 2013: 21). Ronald Bogue in his article The Art of Teaching/Teaching the Arts published in the book Deleuze and Education concludes that the physical sea is the object emitting signs and it is a multiplicity of wave movements. The body's movements do not resemble the movements of the sea, but instead they form a heterogeneous multiplicity responsive to an encounter with the sea as the 'other' heterogeneity" (Bogue 2013: 22).

Lilija Duobliene in the article Learning as Swimming: Imaginational School Project in Deleuzean Way notices that the comparison of the learning with swimming was done long before Deleuze by one of the philosophers who influenced him: Salomon Maimon (1753-1800). According to Daniel W. Smith $(2012,65)$, Maimon's investigations "exerted an enormous influence on Deleuze", correcting the Deleuzean conception of immanence and the concept of difference. Maimon took the allegory of water from his beloved philosopher Maimonid. Maimonid wrote: "He who can swim, may bring up pearls from the depth of the sea, he who is unable to swim will be drowned, therefore only such persons as have had proper instruction should expose themselves to the risk" (Maimonides 1904: 124). Duobliene concludes: "it is clear that for Maimon and Maimonid water is understood as a divine wisdom, which is described in Holy Law. Swimming in the sea means being in a space which has riches such as pearls somewhere very deep. They represent marvelous insights, ideas, and knowledge which can be obtained only if someone is prepared for them. It is a traditional understanding of the teaching / learning process as a matter of working with ideas which belong to a transcendental field. Knowledge in this sense is related not to something unexpected and new, but to something which is valuable, like a pearl, growing for many years, waiting until someone will discover and use it. They are countable and can be reached only by the best students. Creativity in this case is beyond their personal everyday life and the field of immanence. Student can be connected to creativity as the process which is in the disposition of God. It requires following special instructions" (Duoblienè 2014: 141). That is different from Deleuze's approach to learning as swimming.

Duoblienè considers that Deleuze's example of learning as swimming is much closer to another theoretical inspiration of him, Henry Bergson, who also explored the concept of learning as swimming. Henri Bergson providing the example of swimming and learning to swim raised the idea that the reason must be pushed out of its limits by the courage to do so. Duobliene says that "The emphasis is on courage, not on a preparatory process. Jumping means a move from the rational to irrational, from one surrounding / space to another, like the change from walking to swimming"(Duoblienè 2014: 144). She quotes Bergson saying "If we had never seen a man swim, we might say that swimming is an impossible thing, in as much as, to learn to swim, we must begin by holding ourselves up in the water and, consequently, already know how to swim. Reasoning, in fact, always nails us down to the solid ground. But if, quite simply, I throw myself into the water without fear, I may keep myself up well enough at first by merely struggling, and gradually adapt myself to the new environment: I shall thus have learnt to swim" (Bergson 1911: 192). Duoblienè concludes that "in the Bergsonian position such a process of learning and cognition is a risk, a desire to invent new things, the courage to investigate and at the same time create by using intuition and imagination. Such is the process of the creation of oneself, which follows the will to choose this way. Instinct is so strong and alive, which gives the direction for the development of oneself, while the intellect provides some frames for this spontaneous development. Deleuze borrowed the idea of the unconscious, the desire to act in affectation despite unexpected conditions. It is the linkage of body and mind, of the self and the surrounding" (Duoblienè 2014: 144). 
Inna Semetsky also maintains that Deleuze's example of swimming "presents the sea as he epitome of unconscious Nature, rather close to the conception of Unconscious developed by Carl.G.Jung, a literal presentation of fluid uncontrollable forces that produce a shock to thought and make this new experience a struggle for a novice athlete" (Semetsky 2013: 83). Semetsky suggests the concept of bodymind learning for the exact expression of Deleuze's idea. She notices that Deleuze took the example of learning as swimming from Leibniz. Why not from Maimon, or Bergson? Or maybe from all of them three altogether?. In any case, Semetsky wants to emphasize that with this example Deleuze tried to show that learning cannot be based on a priori representation, this would be the reproduction of the same, denounced by Deleuze. Instead "Deleuze emphasizes the "sensory-motivity" of the genuine learner, exemplified in the image of the athlete, who tries to co-ordinate her own sensor-motor activity with an intense, and opposing, force of water, as if evaluating her present mode of existence - sink or swim! Such an evaluation is an effect of the encounter with the unknown, therefore as yet unthinkable. The swimmer becomes an apprentice immersed in the practice of swimming" (Semetsky 2013: 82).

We see a difference between the word athlete used by Semetsky and the word the swimmer (nageur), used by Deleuze. The athlete is an experienced swimmer, who has already learnt how to manage the encounter with the rhythm of the waves. But the one Deleuze is speaking about - la nageur - is the swimmer as the beginner, who is obliged to adjust herself I himself to the unexpectedness of the waves. One can become la nageur even without any intention to swim. One can be just by accident thrown into the water in the same way as one is unexpectedly thrown into existence itself. The wavering sea or ocean used by Deleuze can be also considered as a metaphor for the waving of life. There is no escape from the necessity to swim if one finds herself / himself in the water in the same way as there is no escape from learning. An individual is born in society and he/she obliged to learn how to swim. One should learn to manage to overcome the unexpectedness of new situations finding body motions suitable to remain on the surface. As usual, athletes already know how to move on the surface of the water, they are experienced, but it often happens that the beginners go down into the water and die if they face the necessity to swim unexpectedly and they have not been instructed on the sand by the teacher before. The fear to drown is one of the fears of learning. This can be exemplified by an unsuccessful case of studying at university of the Nomadic Student, an example which will be discussed later. The fear to drown can be also the reason for drowning. Semetsky sees the problem as the dramatic, even Kierkegardian, choice: either/or. "Sink or swim", as emphasized Semetsky, is the choice between life and death. Maimon and Maimonid had in mind the same dramatic choice of the situation in education when they said: "He who can swim may bring up pearls from the depth of the sea, he who is unable to swim will be drowned, therefore only such persons as have had proper instruction should expose themselves to the risk". Maimon and Maimonid, contrary to Deleuze, suggest the value of the instruction. I would argue with Deleuze and would support Maimon and Maimonid's idea. The learner (swimmer) and the teacher (instructor) are united not only by sensomotor- bodyspace actions, but also by the imagination as the experimental field. One cannot experience by bodymind learning all the unexpected situations before they happened in reality. Mainly, unexpectedness of the possible situations makes the instruction valuable for learning. As Paul Ricouer suggests literature is the laboratory for the learning to die ( see: Ricouer 1990: 192). Philosophy is also the school how to overcome the fear of death, taught by perfect instructors philosophers - since Antiquity. The instruction about the rules and practice of social communication before entering university would have helped the Nomadic Student as well. Sometimes a practical remark or simple instruction can be the main decisive point for life in very dangerous unexpected situations. I would argue by an example taken from a very personal experience that happened years ago. At this time I was already an experienced professor but inexperienced driver. My learning to drive was very much in bodymind style as suggested by Deleuze: no professional teacher, mostly senso-motor learning. I learned the rules by myself and followed the suggestions of two non-professional advisers. The first one was driving himself, while the second one even did not drive, but had the experience of being carried in a car by a very professional driver. In half a year of driving, I felt rather self-confident, not as a beginner swimmer, but as an experienced athlete. I was learning to drive in autumn when there was no snow. In February after the first night of snowing I had to go three hundred kilometers away to the sea to give lectures on philosophical ethics. Being afraid of the getting late and feeling quite confident as an experienced swimmer (imagining, that I am an athlete), I was speeding and pulled out to overtake two cars at once. At that particular moment of this quite habitual action when I was overtaking two cars, I suddenly understood that I felt an icy patch on the road and my car suddenly skidded to the right becoming uncontrollable. It took a very small part of the second to decide what to do in this particular situation. I remembered somebody instructing me before (even difficult to remember who particular - do not remember the teacher as the person - the one who was emitting the signs, it seems she/he was not very important) that in this situation the first uncontrollable turn of the car would be to one side, while the second turn will be to the other, and the third and the last turn, which would overturn the car, would be again in the direction of the first turn (it means to the right of the two cars I tried to overtake). The instruction was the 
following: one should catch the moment of the second turn and succeed to turn the steering-wheel to the same particular direction. I followed the instruction and I did it. My car started to fly like in the movie and succeeded to land on the left side of the road without any visible damage and not overturned; this way saving the other two cars I was trying to overtake. The success of the action proved the truth of the instruction and suggested the belief in the power of representation and usefulness of logocentrism in extremely difficult situations (joke!). I feel no desire to repeat this situation and to persuade myself or the world how particularly experienced I am in flying with a car. Many thanks to the unknown instructor who saved the lives of all in this situation. Very often in an existentially extreme situations when one does not know what the decision should be taken very quickly and fatally, one asks oneself: what would my teacher, it means the person I trust, do in this situation. And very often technical advice of anonymous instructors or wise insights of thinkers help one to overcome the unknown situation the swimmer has never experienced before.

But on the other hand, looking at the learning process sub specie aeternitatis, one can notice that the idea of learning not from instructions but from the supposition "do with me" usually takes place in the development of deep structures of the personality. The metaphor of waves and the sea in the process of learning was used by the Lithuanian poet and laureate of the National prize literature Aidas Marčènas, when he tried to reflect about the very origin and birth of his creativity. To reflect the creativity he suggested two concepts: bodysurfing and soulsurfing. The bodysurfing is the ability to swim on the wave. "My father taught me in the childhood to catch the breaking wave and to slide with the body on its surface. Actually, he did not teach. Just used to catch the breaking waves himself and I was learning from him". The writing of poetry, says Marčenas, is a very similar matter. Only it is soulsurfing: the waving of soul. The poet is the catcher of the waves of the soul who is attending and waiting for the breaking wave in the shallows (Marčennas 2006: 412 ). Who is emitting signs in this case: the sea or the father? It seems the father is the main teacher, but the sea as the metaphor of life is waiting behind.

\section{Schizoanalysis in Education: How to Educate Those Who are Sinking?}

Where is the teacher's place in this bodymind education by signs emitted by the sea? Deleuze wrote: "When a body combines some of its distinctive points with those of a wave, it espouses the principle of a repetition which is no longer that of the Same, but involves the Other - involves difference, from one wave and one gesture to another, and carries that difference through the repetitive space thereby constituted. To learn is indeed to constitute this space of an encounter with other, and repetition takes shape while disguising itself" (Deleuze 1994: 23). Bogue concludes that "genuine teachers, it turns out, are simply emitters of heterogeneous signs that help students to encounter other heterogeneous signs. In learning to swim then, whether the signs are emitted by the sea, or by the genuine maiter the signs themselves are the teachers" (Bogue 2013: 23). After this conclusion, Bogue thoroughly discusses the case of Deleuze as a successful teacher, as an emitter of these heterogeneous signs.

Deleuze had the heterogeneous conception of teaching. After retirement when he reflected on his own practice of teaching philosophy, Deleuze compared it to a piece of music: he suggested imagining it as a rock concert, where the listeners are from very multiple spheres: the first-year and nth-year students, students and non-students, philosophers and nonphilosophers, young and old, and many different nationalities. There were always young painters and musicians there, filmmakers and architects. It seems that Deleuze was fascinated by this multiplicity and did not see his aim as a philosophy professor of "building up knowledge" progressively (Deleuze 1995: 139). He was interested in arts and used to learn from different artists, including his own students. The musician Criton as a student remembers: "He didn't pretend to be a musical specialist. It was a laboratory, live thinking taking form. He used to say to me, "Is this right?" Can I say it this way?" (Dosse 2010: 446).

In any case, Deleuze during his teaching career was giving traditional lectures. During them he tried to demonstrate the very event of the birth of the thought to his students.

But not all the cases in teaching process are so successful. How to educate those who cannot accept the signs emitted by the teacher and cannot recognize and acknowledge the importance of the Other in the process of learning? There is a notorious example of the student who rejected Jacques Lacan's teaching at the lecture at Lyon's university by pouring water from the glass into the teacher's face.

The famous example of the student who denied the signs of the teacher not for the reason he did not recognize them but for the reason of the drive to impose his own signs instead of the teacher's was Antonin Artaud - the inspirer of some Deleuze's ideas(for example, body without organs). Artaud had a natural instinct for the theatre, but it was difficult for him 
to secure his work as an actor. Later his first employer wrote that he had responded to the 'poetic flame in the spirit of Antonin Artaud', though the young man's hesitant diction 'made it difficult for him to get started'. Lugne-Poe reflected: "this astonishing artist... His make-up, his poses were those of an artist lost among actors.' He described Artaud as 'sensitive in the highest degree, intelligent, tormented with beauty'. But he never again employed him (Hayman 1977: 41). Artaud was accepted by the theatrical teacher Charles Dullin who had founded a theatrical company l'Atelier, later named as the Théâtre de l'Atelier. Dullin was also running a school for actors. Artaud understood the principles of Dullin's teaching quite deeply. He wrote about Dullin's principles of teaching as the interiorization of the actor's activity: "he wants his production to give the impression of never having been seen. Everything takes place in the soul...His ideal is Japanese actor who plays without props... It's curious, to say the least, that with my tastes, l've happened on something so in tune with my mentality" (Hayman 1977: 42). But Artaud did not find it easy to adapt himself to the principles of Dullin's teaching and to the communal life of the school. Dullin later reflected: "He followed us at a distance - a little ashamed. Apart from that, his application and willingness were exemplary, except with the mechanical exercises in diction. He energetically refused to do these" (Hayman 1977: 43). Artaud also had no respect for Dullin's conception of realism. He appeared with a Chinese mask when he played the town council in Pirandello's The Pleasure of Honesty. Dullin was not pleased. When playing the Emperor Charlemagne in Alexandre Arnoux's play Huon de Bordeaux, Artaud totally rejected the teaching of Dullin and made one of his entrances on all fours crawling towards the throne. Later he dismissed Dullin's protest with contempt ('If it's realism you want, oh well!'). The cooperation between Artaud and Dullin could not last any more. The teaching project was over. Artaud rejected the teacher's signs. Artaud created his own conception the "Theatre of Cruelty". He succeeded to make only one performance which was not success. But Deleuze says he is on the side of Artaud. He is on the side of the rejection of the vertical type of learning: teacher as an authority. Just bodymind learning. But how is it possible to gain the mastership of some professions without the authority of the teacher as an expert authority? How to become a master? Is it possible to become a philosopher without the studies at university? Is it possible to become a talented poem or writer without studying at university?

The examples of Jorge Luis Borges, Russian poet Josif Brodsky and already mentioned Lithuanian poet Aidas Marčènas show; that in some cases of creative professions it is possible. During the Soviet time in 1964, Brodsky, who later lived in the USA and became the laureate of the Nobel Prize in Literature, was taken to court charged with laziness and avoiding of socially useful job (social parasitism). Soviet authorities decided that his series of odd jobs and his role as a poet were not a sufficient contribution to the society. During the trial, the judge asked him very severely where he had learnt the profession of being a poet. Brodsky hesitated for the reason he had no university education and replied quite sincerely saying: "I thought it is from God". Later in his life Brodsky commented that many of his teachers were anti-Semitic and that he felt like a dissident from an early age. As a young student, Brodsky was "an unruly child" known for his misbehavior during classes. At fifteen, Brodsky left school and tried to enter the School of Submariners without success. He went on to work as a milling machine operator. Later, having decided to become a physician, he worked at the morgue, held a variety of jobs in hospitals, in a ship's boiler room, and went on geological expeditions. At the same time, Brodsky engaged in a program of self-education. "But while Brodsky left school as soon as he legally could, he still yearned for some sort of formal education. He enrolled in evening classes and audited lectures at the university. The eventual breadth and depth of his knowledge, however, was ultimately due to his own tireless eff orts to educate himself. As a young man, he taught himself English and Polish; later he would learn to read Latin, Italian, and French. Toward the end of his life he began studying Chinese (Loseff 2011:19). When asked about the time when he first felt calling for poetry, he recollected "In 1959, in Yakutsk, when walking in that terrible city, I went into a bookstore. I snagged a copy of poems by Baratynsky. I had nothing to read. So I read that book and finally understood what I had to do in life. Or got very excited, at least. So in a way, Evgeny Abramovich Baratynsky is sort of responsible (Shtern 2004: 63). In 1960, the young Brodsky met Anna Akhmatova who would go on to become his mentor.

Borges's parents took him together with sister from Argentina to Geneva in Switzerland in order to give them a good education. When Borges graduated from a high school, the family returned to Argentina, but he never entered a university and learned by himself, following his father who used to go to the libraries. His father was a psychologist and was interested in William James. Borges did not know what particular books he wanted to read, he was too shy to ask the librarian for advice so he took encyclopedias from the shelves and read. Without a university diploma, he ended his career of being a university professor of English literature. On the other hand, many universities in the world were inviting him as an honorable lecturer (see Burgin 1968). Aidas Marčènas took a course of actor's mastership at the Academy of Theatre and Music in Vilnius for a short period of time. But because of his bohemian style of life he was excluded and later became one of the 
best contemporary Lithuanian poets. When asked about his education, he usually remembers his job as a worker at the Botanical garden, his travel in the wagon for animals from Lithuania to Siberia in or der to sell cows. He also remembers his work at the Opera and Ballet House as the gaffer. But when asked who was his mentor, his main teacher for his creation, he always mentions only the musician Frank Zappa, whom he never met in his life. All these cases, Borges, Brodsky and Marčènas, are perfect examples of bodymind learning swimmers, who manage to learn the lessons of life and to find the productive place in society from their own bodymind movements. All of them became attached to literature being inspired by virtual teachers (Poe, Baratynsky, Zappa) they never met in their lives. They never had real teachers. Swimming without a teacher as an authority can give the best result for the swimmer who feels he/she is able to say something new to the world. What would have had happened if any of them had decided to go to a traditional university? Would have such project succeeded?

The lack of real authority as if liberates the space for the learning in bodymind manner. One did not need to study in the official institution in order to live an interesting life and to become famous. The example of N.S. (let's call him for the purposes of conspiracy N.S.: Nomadic Student), who tried to study philosophy at one of the universities of the European Union ended up in a clash between him and professors as authorities in one month, is the best example of state institutions being inadequate for successful bodymind learners. N.S. is a practicing photographer and he is known in society not only for this profession but also for his nomadic style of life - his permanent travels.

His beloved continent for travelling was Latin America. He travelled in Argentina, Chili, Uruguay, Brazil, Paraguay, Bolivia, Peru and Ecuador. According to N.S., every time he visited a different country he tried to see the things he had not seen before. Nature, food, folklore, the manner of communication in every country seemed different. In Patagonia the nature is wonderful. Bolivia is the country which kept its brand and the heritage of the Indian culture. Peru is famous for its gastronomy. Ecuador is the pearl of the continent. N.S. travelled alone on his bicycle around the famous lake Isikul in Kirghizia. To the question why he looks at the world through the photo camera, the traveler answers: "For the reason that it lasts only a part of a second".

The photographer nomad is learning from differences: from the signs the world is emitting round. He did not graduate from any special photographer's school. But there is no need - the Union of the photographers accepts him as a member. He arranges exhibitions and gives interviews. In this process of bodymind learning, the most complicated and perhaps not possible thing is to learn from other people. He takes pictures of people from different countries, preferring the faces of the children. But he approaches them only as the objects of his photos, not as partners of a possible dialogue. He knows in advance - the humans beings are not worth of putting effort to communicate with. He says: "Some of them are too good, some of them are too stupid, some of them are too serviceable. Sometimes being too good they can do much evil". His aim is to distance himself from the people. The lake, the mountains, the sky are friendly and accepting the traveler. They are stable. But people around make strange decisions. The traveler tells to the journalist a story about a man in Kirghizia who openheartedly insisted that he would enter his house. The traveler hesitated because of the bicycle, but at last when he agreed and entered the house, his bicycle fell and the casing was damaged. But the man did not help him to repair his bicycle. "Sometimes too good people have no conscience", the traveler concludes quite paradoxically. One can see that in this process of bodymind learning this particular traveler does not need the Other to complete his training.

On the spur of the moment, the traveler decided to change the style of his life and to find a place of stability in the world. Therefore, at the age of thirty-six he enters university to study philosophy. The hero of Deleuze and Guattari's conception of nomadic education enters into the area of practical vertical learning action. After the intriguing nomadic life of the explorer of the universe the student is not able to concentrate and to listen to others who speak, including professors. It is too boring for him. He is more inclined to speak himself. The professors try to suggest rules and to restrict the time for his speaking and limit the amount of the questions he is raising (some of his questions are interesting, his colleague students notice). But this is restriction of his freedom - the jail of vertical type of learning. The student is furious. He is going to fight. He feels deep injustice rising from the vertical mode of education and challenges the professors as authorities, sometimes with the open contempt. As a student he in not open to the signs emitted by the professors. The professors ask to observe formality of communication during lectures. He refuses to obey because he does not understand the meaning of the requirement. On the one hand, he feels tension and he feels being persecuted. On the other hand, he feels quite strong to teach the professors the lessons of justice. He expects them to comply with his behavior or they will be punished. This is his decision. He writes a lot (hundreds) of complaints. He writes them almost every day. This activity gives him a feeling of the investigator: he is researching the imperfection of the educational system of the university. He does not search for the 
modes how to accommodate and to adjust to the new situation. The previous experience of the life lived before does not help. On the contrary, it does not allow the student to accept the role of the student who identifies himself with the reader of Plato. He is accustomed to act in the different type of the assemblage. It is much more intriguing to be the writer of complaints. He writes them in a nice literary manner. During the meetings of the Commission of Ethics at the level of the faculty, later on at the level of the university, later on at the level of the of the institution of Controller for the academic ethics and procedures for all the country that investigate this case, he reads his complaints in an expressive manner standing in front of the commissions, which usually consist of professors. For his expressive reading he needs a particular pose. When proposed to stop writing complaints and start writing essays on Plato or Aristotle, he sincerely answers he would like to do this, but he cannot. He has to fight against the injustice and he has a desire that all the professors who lectured him the philosophy for one month should be punished for badly treating him as a person. He used to record his fights with professors, and finally, at least three of them were punished by the official Controller for breaching academic ethics and procedures. This was announced all over the country and the judgments of the official Controller may have serious impact on their future academic career. N.S. cannot feel satisfied for the reason that the professors wrote ae complaint to the same Controller concerning his behavior as a student. He responds energetically: he sends his complaints concerning the misbehavior of the professors to all the employees of the university and goes to the press. He is famous, he is a Nomadic traveler, investigator of different aspects of the planet, the knight of feeling differences and the knight of deteritorialization in Deleuzian sense. Thus, he gets response to the complaints. One of the main online newspapers publishes an article with the headline saying that three academically guilty professor are seeking for revenge on the student who fights against the corrupted university all alone. The article is illustrated with the photo of one guilty in advance professors, who was the leader of the course. In some days, one more article appeared with the same photo of the same professor exploring N.S. complaint that the professor during the course of the Philosophy of Antiquity suggested him to commit a suicide. The professor only discussed how this problem was understood in the philosophy of Antiquity but N.S. does not feel the distance between the word and reality. The word 'suicide' injures him as if it is a real thing: for example, a knife. It started to begin the matter of public discussion. Alumni students responded with the support to the professor they loved and respected. They said "It is surrealistic" (N.R.), "Somebody is trying to eliminate talented lecturers" (G.G.), "I was happy I was his student" (L.K.), "I would like to sit in his lectures so much again" (L.K.), "It is really happiness....and now I am delighted that such a nice person educated us. I am doing quite a different job, but a huge part of my achievements is due to our wonderful professors...You are my superheroes". During the accreditation of the program, international experts noticed as a weakness that this particularly university does not provide enough formal structures for staff development, but, on the other hand, they concluded that "the staff are research active, and have considerable experience in teaching. The staff have considerable expertise in publishing teaching materials. The staff have very good reputation with students, graduates and employers".

The main professor whose photo was published in the online newspaper as the main authoritarian figure of vertical education is also a writer, a poet and also a commentator in the same online newspaper. So he commented on the situation without using names describing this conflict ironically as the fight between cats and the mice, like the play in the power game. In this particular situation, the student feels he is a cat, and professors are mice. The journalist who helped N.S. with publications also felt she is able to play the role of a cat in this situation. The Controller for the academic ethics and procedures for all the country at least decided that the student is also guilty because he broke the rules of ethics established by the university. The University has the right to suggest him to leave this particular university. But the problem is not solved. The question still remains open. What is the Nomadic Student supposed to do with his life after these unsuccessful lessons of swimming not in the life, but in the academic water, which requires new movements? Maybe not so much bodymind, but on the contrary soulbody. The Nomadic Student has a deep desire to become academically experienced. He continues to investigate further every text the University publishes concerning this course and continues to write his complaints every day instead of reading Plato. He is collecting material for the further fight. He tells everybody he is writing a book about low levels of education. All the means in this fight are suitable for the reason the enemy (the mouse) is very strong and he is fighting almost alone (only his wife comes the meetings to support him). Thus, in the letter to the Dean of the faculty he wrote that while writing the letter he noticed that it is the full moon and at this period many people become nervous. N.S. asks the Dean with an obvious hint: how he being such a clever person did not notice how many homicides are committed during the full moon. Or maybe he wants him to commit a suicide? It would have been a very bad example for all the people he is connected with, including professors and the members of Seimas. N.S. reproaches the Dean that mainly he is creating such a destructive situation for all the society around. 
Some young professors who were the involved in this clash in the role of the mouse refuse to lecture to him even at a distance using virtual academic ways of teaching any more saying they would better leave the university as their working place. A young lecturer who did not happen to formally meet N.S. and who is only an observer concluded that he is not living in reality. He is intoxicated by the feeling of his own omnipotence and by the plot of the story he is creating himself.

How can we help the student and the staff to reflect and to solve this difficult academic situation? Maybe it is time to invoke the schizoanalysis suggested by Deleuze and Guattari.

\section{The University is not A Factory of the Shoes, but is it the Psychiatric Clinic?}

The Deleuze and Guattari's insight may help a lot to support the student's position which in this particular case became socially rather vulnerable. He exposed himself to the public debate and in the internet discussion is accepted as an example of autism and the one who prefers quarrelling instead of productive cooperation. The support for him would be the book Anti-Oedipus: Capitalism and Schizophrenia (L'Anti-Oedipe. Capitalisme et Schizophrénie: 1, 1972 ) by Deleuze and Guattari in which they opposed the vertical structure of Freud's psychoanalysis when the therapist is on the top of the situation. In the situation of education, the place of the top of the relation is taken by the teacher or by the professor. In this book Deleuze and Guattari opposed the Oedipus triangle structure in psychoanalysis, based on the narrow family triangle: me/mummy/daddy and suggested instead the concept of unconsciousness as a machine of production. They draw a parallel between desiring production and social production. The social arena is the field of desires. Unconsciousness is a machine of production: "We consider the unconscious to be a factory rather than a theatre". The unconscious produces not because of the lack but because of the will to produce. As Dosse notices, Deleuze and Guattari were not writing a defense of schizophrenia. They wanted to schizophrenize the unconscious to get rid of the Oedipal, familiarist scaffolding of psychoanalytic practice (Dosse 2010: 199). Sixteen years later talking in the Abécédaire made with his former student Claire Parnet, Deleuze reflected that in this schizoanalysis of desire they had not intended to address general longing but rather the transition from an abstract notion of desire to a constructivist approach that addresses the concrete arrangements in which desire expresses itself. "All desire flow from an arrangement. To desire is to construct an arrangement". Deleuze also repeated : "the unconsciousness is not a theatre but a factory of production, mental illness is not at all what psychoanalysis makes of it since it bears the entire world and desire constructs multiple arrangements" (Dosse 2010: 220).

This particular book can be the leading book for our Nomadic Student in the same way as it was for revolutionary leftists in the West, in the case he would be able to understand what is written in it. But the requirement to understand the ideas in the book requires the ability to understand Plato, Aristotle, Kant, Nietzsche, Marx and all the other thinkers Deleuze and Guattari are discussing with. Is it possible without vertical university education based on professors authority?

In order to go beyond the Oedipal triangle, Deleuze and Guattari in this book referred to the example of Daniel Paul Schreber and also to the institutional psychoteraphy being practiced at La Borde clinic where the subject and the subject groups were distinguished and where the very idea of individual fantasy came under fire. They tried to de-Oedipalize the unconscious to get to the real problems. It is not mom and dad who cause the delirium but rather the world. They say: "Every delusion has an historical-global, political, racial-contest". The schizophrenia that Deleuze and Guattari were brandishing was not the illness of the same name. It was a universalizing program, a limitless process, a constantly reiterated ability to transgress limits, to carry out a release. They believed that this process was at work in Anglo-American literature, which Deleuze particularly appreciated. It was also the case of Artaud: "Artaud is the culmination of literature, precisely because he is schizophrenic and not because he is not. He long ago broke the wall of the signifier: Artaud and Schizo" (Dosse 2010: 199).

The situation in this particular case of the Nomadic Student from the very first look seems similar to the one discussed by Felix Guattari in Chaosophy: Texts and Interviews, when the patient-analyst's relation as superego and ego meeting creates destructive and traumatizing signifying regime alienating him from the fabric of social life. N.S. complains: "they left me alone in the audience, I felt traumatized. I felt tension for all these months. They all were against me". Guattari opposed the vertical structure of social communication in traditional psychiatric clinic. "Amongst psychotic patients, Guattari observed, the verticalization of subject roles produced paranoia, misunderstanding, and feeling of isolation from institutional life. Under such conditions, patients regressed into non-communicative and sometimes violent states (Guattari 2009). In turn, noticed Wallin, staff armored themselves against the depressive detachment of their patients while protecting themselves from their own sense of alienation within the institutional order. Guattari's militant molecular revolution of the clinic is called as the 
project of transversality. Guattari repeated Oury words that "the clinic should not resemble a "shoe factory" ordered by way of specialist roles, rigid forms of management, and routinized modes of production" (see: Wallin 2013: 42).

In order to overcome this segregation and isolation from social life his patients Guattari together with Oury tried instead of traditional face-to-face patient's treatment based on analyst's authority to suggest transversal group-subject therapeutic relationship

If Guattari would have discussed the case of the Nomadic Student, he would have concluded that his desire to overturn the social hierarchy and to take the stance of the one who judges and who controls the situation (the cat's position) stems from the social sources and from his alienation from the vertical institutional life.

And here the paradoxical aspects of bodymind learning, which is until this moment only theoretical, enter into the play. Is one able to learn the philosophy and to become a professional philosophy teacher only by bodymind education? If the student rejects the learning as representation, he does not feel deeply obliged to study seriously the texts of Plato or Aristotle. The vertical structure of teaching at university requires some necessary traditional abilities: to concentrate attention and to follow the main idea a professor is trying to present during the lecture, the ability to hear the argument of the others and respond to them in an adequate way. Is this possible to learn only by bodymind education? Can the principle of transversality which Guattari and Oury successfully applied for treatment mentality ill people be still valid when applied in university education? Ted T. Aoki in his research is trying to prove that it is valid. But in this particular case of the Nomadic Student we conclude that it would not work. He feels contempt for the professors and for the university and takes for granted that it is not his level. And he feels injured by the persons from this university. He desires only revenge. But he also desires to study. It can be concluded that the Guattari example of transversal groups for solving concrete problems consisting from students, professors, psychiatrists, psychologists, maybe even priests, etc., not at the university level would be helpful for both the students and the professors when such paradoxical clashes occur. It is necessary to solve the problem of the adjustment to the situation and the problem of the reintegration into the social life instead of giving a verdict of the vertical institution of Controller for the academic ethics and procedures for all the country, which only receives complaints and judges who is guilty to be blamed and punished officially. There are no guilty persons in this situation, only the deep gap in communication. Deleuze also had a clash with a student. Clashes between professors and students are the normal course of the life as an ocean. Even for such successful professors as Deleuze was. His student, an elegant homosexual Michael Cressole, wanted to write a book about his teacher. But Deleuze refused to help him to carry out this plan. Cressole began to loathe his former idol and he tried to destroy Deleuze "as he is spoken of". He denounced Deleuze as the great ring-leader of Vincennes, where all kinds of unsavory demands were made by a rigid Master, who was suffocating in a little smoke-filled hall. He described the Anti-Oedipus as "fantastic toy" that two "mad geniuses" had made available for kids. Deleuze answered: "You're charming, clever, mischievous, and even vicious sometimes. You might try to be a bit nicer" (Dosse 2010: 216). At some American universities where guns are available, such clashes sometimes end with real shootings.

\section{Conclusion}

And the vertical style of teaching as a matter of fact has little to do with it. The feeling of drowning when others are successfully swimming around is the feeling of great despair and deep frustration the student is not able to overcome alone. It is the injustice of the life itself, as would Friedrich Nietzsche have said. The shooters as usual are the ones who have not learned to catch the wave in the sea of the abstract ideas and to experience pleasure from swimming in it. That is why they are overwhelmed by the deep desire for the others to be drowned together. Dosse noticed that Guattari succeeded to cure one very deeply autistic young person by communicating with him patiently for long time. But it was in La Borde clinic. Not in Vincennes university where Deleuze lectured.

\section{References}

[1] Beighton C. (2015) Deleuze and Lifelong Learning: Creativity, Events and Ethics. Palgrave/Macmillan.

[2] Bogue, R.(2013) The Art of Teaching/Teaching Arts. In Deleuze and Education. Ed. Inna Semetsky and Diana Masny. Edinburgh: Edinburgh University Press, pp. 21-36.

[3] Burgin, R. (1968) Conversations with Jorge Luis Borges. New York: Avon Books.

[4] Deleuze, G. (1968) Différence et répétition. Paris: Quadrige/PUF.

[5] Deleuze, G., Guattari, F. (1972) L'Anti-Oedipe. Capitalisme et Schizophrénie: 1. Paris: Les éditions de minuit. 
[6] Deleuze, G., Guattari, F. (1983) Anti-Oedipus: Capitalism and Schizophrenia. Trans. Robert Hurey, Mark Seem, Helen R. Lane, Minneapolis: University of Minnesota Press.

[7] Deleuze, G. (1990) Negotiations, 1972-1990. Trans. Martin Joughin. New York: Columbia University Press.

[8] Deleuze, G. (1994) Difference and Repetition Trans. Paul Patton. London and New York: Continuum.

[9] Deleuze and Guattari: Politics of Education: For a People-Yet-To-Come. Ed. Matthew Carlin and Jason Wallin. New York, etc.: Bloomsbury Academic, 2014.

[10] Deleuze and Education. Ed. Inna Semetsky and Diana Masny. Edinburgh: Edinburgh University Press, 2013.

[11] Duoblienè, L. (2014) Learning as Swimming: Imaginational School Project in Deleuzean Way. Žmogus ir žodis / Filosofija Man and the Word / Philosophy. 2014, vol. 16, No. 4, pp. 140-148.

[12] Guattari, F. (2015) Psychoanalysis and Transversality. Texts and Interviews 1955-1971. Trans. A. Hodges. Semiotext(e)

[13] Expanding Curriculum Theory. Dis/positions and Lines of Flight. Ed. W.M.Reynolds and J.A.Webber. New York: Routledge, 2016.

[14] Hayman, R. (1977) Artaud and After. Oxford, London, New York: Oxford University Press.

[15] Loseff, L. (2011) Joseph Brodsky. A Literary Life. Trans. Jane Ann Miller. New York, London; Yale Univristy press.

[16] Maimonides, M. (1904). The Guide to the Perplexed. London: Routledge \& Kegan Paul Ltd.

[17] Marčènas, A. (2006) Eilinè. Vilnius: LRSL.

[18] Nomadic Education. Variations on a Theme by Deleuze and Guattari. Ed. I.Semetsky.Rotterdam/Taipei: Sense Publishers.

[19] Olsson, L., M. (2009) Movement and Experimentation in Young Children Learning. Deleuze and Guattari in Early Childhood Education. New York: Routledge.

[20] Expanding Curriculum Theory. Ed. W. Reynolds and J. Weave. New York: Routledge, (2002) 2016.

[21] Ricoeur, P. (1990). Soi- même comme un autre. Paris: Editions du Seuil.

[22] Roy, K. (2003) Teachers in Nomadic Spaces. Peter Lang., Inc.

[23] Semetsky, I. Masny, D. (2013) Introduction: Unfording Deleuze. In Deleuze and Education. Ed. Inna Semetsky and Diana Masny. Edinburgh: Edinburgh University Press, pp. 1-20.

[24] Semetsky, I. (2013) Learning with Bodymind. In Cartographies of Becoming in Education. A Deleuze-Guatatri perspective. Ed.Diana Masny. Rotterdam: Sense Publishers.

[25] Smith D.W. (2012) Essays on Deleuze. Edinburgh: University Press.

[26] Shtern, L. (2004) Brodsky: A Personal Memoir. Baskerville Publishers.

[27] Wallin, J. J. (2010) A Deleuzian Approach to Curriculum. Essays on a Pedagogical Life. New York: Palgrave/Macmilan.

[28] What is Art Education? After Deleuze and Guattari. Ed Jan Jagodzinsky. New York; Palgrave, Macmillan, 2017.

[29] Whistler, D. (2012). Salomon Maimon Essay on Transcendental Philosophy. Journal of Jewish Thought. Toronto: The University of Toronto. Issue 3.

[30] Usher, R., Edwards R.(1994) Postmodernism and Education.Different Voices, Different Worlds. London, New York: Routledge. 